\title{
Associated Vibrio Species in Shrimp Vibriosis from Traditional Brackish Water Pond in the North Coastal of Central Java, Indonesia
}

\author{
Sarjito ${ }^{1, *}\left(\mathbb{D}\right.$, Agus Sabdono $^{2}$
}

${ }^{1}$ Diponegoro University, Faculty of Fisheries and Marine Science, Department of Aquaculture, Jl. Prof. Sudharto, Kampus Tembalang, Semarang, Indonesia 50275.

2Diponegoro University, Faculty of Fisheries and Marine Science, Department of Marine Science, Jl. Prof. Sudharto, Kampus Tembalang, Semarang, Indonesia 50275.

\section{How to cite}

Sarjito, Sabdono, A. (2021). Associated Vibrio Species in Shrimp Vibriosis from Traditional Brackish Water Pond in the North Coastal of Central Java, Indonesia. Genetics of Aquatic Organisms, 5(2), 211-224. http://doi.org/10.4194/2459-1831-v5_2_01

\section{Article History}

Received 18 November 2020

Accepted 15 February 2021

First Online 16 February 2021

\section{Corresponding Author}

Tel.: +62247474687

E-mail: sarjito_msdp@yahoo.com

\section{Keywords}

Diversity

Vibrio

rep-PCR

Brackish water

North Coast of Central Java

\begin{abstract}
Indonesian shrimp cultures are threatened by vibriosis. Some traditional brackish water ponds remained along the north coast of Central Java after the disease outbreaks destroyed the shrimp culture. This study aimed to discover the Vibrio diversity associated with shrimp vibriosis in traditional brackish water ponds. An exploratory method with purposive sampling was used in this study. Twenty-four shrimps presumably infected with vibriosis were collected from two district regions on the north coast of Central Java in July-September 2018. The bacteria associated in shrimp vibriosis were isolated from the telson and inner part of the hepatopancreas with TCBS medium. Forty-one bacteria associated with shrimp vibriosis were obtained, and then repetitive-polymerase chain reaction (rep-PCR) was performed to obtain Vibrio strains. On the basis of rep-PCR results, five respresentative strains were selected for further study. The results of $16 \mathrm{~S}$ rDNA sequence analysis showed that the JKP03, JKP05, JKP19, JKM01, and JKM06 isolates were closely related to Vibrio rotiferianus, Vibrio diabolicus, Vibrio parahaemolyticus, Vibrio alginolyticus, and Shewanella algae, respectively. Vibrio biodiversity in shrimp vibriosis was high. These results confirmed that traditional shrimp farming was susceptible to vibriosis. Therefore, control methods such as vaccines, probiotics, and immunostimulant formulas must be developed to prevent and control the outbreak of shrimp vibriosis in traditional brackish water pond.
\end{abstract}

\section{Introduction}

Shrimp is an important aquacultural species with high economic value and the most important export commodity from Central Java, Indonesia. Some brackish water ponds remained along the northern coast of Central Java after the disease outbreaks destroyed the shrimp culture business in the 1990s (Hariati et al., 1995). The culture species in this area include Peneaus monodon and Litopeneous vannamae, and their production has still steadily increased. They are commonly cultured using semi-intensive and traditional techniques. Most traditional shrimp farmers apply low external input for sustainable aquaculture by optimizing local resources, such as using liquid compost from fermented organic waste from households for curing pond bottom and maintaining pond water quality (Ariyati et al., 2019). Farmers also practice an integrated mangrove-shrimp aquaculture system as Indonesian government's program to rehabilitate and conserve the mangrove forest. Although this system is more ecologically friendly than other types of aquaculture, shrimp production is still low. Improper culture management, such as drainage of pond bottom and 
relying on a single sluice gate for water flow, causes viral and bacterial disease problems and results in mass mortality (Sarjito et al., 2012; Uddin et al., 2013; Liu et al., 2016). Some farmers use chemicals, such as antibiotics, to combat vibriosis in shrimps. Antibiotic residues and antibiotic-resistant bacteria emerged in the brackish water pond environment because of excessive antibiotic dosages. Therefore, vibriosis outbreak has become a problem in shrimp culture in Indonesia (Isnansetyo et al., 2009; Istiqomah et al., 2020) and other countries (Abdelaziz et al., 2017; Mastan \& Begum, 2016).

Vibrio is the causative agent of vibriosis, a common disease in aquaculture worldwide (Akaylı \& Timur, 2002). It can infect crustaceans, mollusks, and fish, resulting in mass mortality. Vibrio infection in shrimps is characterized by pale hepatopancreas, reddish or pale body carapace, reddish uropod and telson, and red antenna (Sarjito et al., 2018). Although Vibrio is a normal part of the bacterial flora in the estuarine and seawater environments, several Vibrios are opportunistic pathogens in cultured shellfish, finfish, and shrimp (Austin \& Austin, 2007). Therefore, Vibrio may cause serious production loss in shrimp culture (Stalin \& Srinivasan, 2017). Vibriosis causes mortality in larvae and adult stages by up to $50 \%$ (Lightner, 1996).

Most previous studies reported that vibriosis is related to the Family Vibrionacea, mostly of the Genus Vibrio. However, Shewanella algae and Listonella have been grouped in Vibrionaceae (MacDonell \& Cowell, 1985). Well-known causative agents of vibriosis are V. vulnificus, V. fluvialis, V. damsela, V. fischeri, $V$. parahaemolyticus, and $V$. alginolyticus (Chythanya et al., 2002; Kumar et al., 2014; Gopala et al., 2005). Chandrakala and Priya (2017) have mentioned 14 Vibrio species acting as shrimp pathogens: $V$. harveyi, V. splendidus, V. parahaemolyticus, V. alginolyticus,
V. anguillarum, V. vulnificus, V. campbelli, V. fischeri, V. damsella, V.pelagicus, $V$. orientalis, V. ordalii, V. mediterrani, and $V$. logei.

Many studies focused on the Genus Vibrio in the aquaculture system (Liu et al., 2016; Sarjito et al., 2018; Gopala et al., 2005). However, most research involved mono species and intensive culture technologies. The current study aimed to elaborate on the medical symptoms of shrimp infected with Vibrio. A molecular approach was used to identify the causative agent of Vibrio related to vibriosis. Studies on the Vibrio diversity causing vibriosis in traditional brackish shrimp ponds are limited. The accuracy of the molecular method for identifying Vibrio is important to mitigate and design disease prevention strategies for sustainable shrimp production. Considering vibriosis outbreaks has become an important limitation on shrimp production in Central Java. In addition, bacteria such as Vibrio cholerae can also cause human infections. Therefore, to discover Vibrio diversity associated with vibriosis in shrimps is urgently needed. The current study aimed to develop a simple reliable molecular protocol to identify Vibrio associated with vibriosis in the shrimp of traditional brackish water pond on the north coast of Central Java.

\section{Materials and Methods}

\section{Shrimps Sampling}

Exploratory method with purposive sampling was used in this study. Shrimp specimens presumably infected with vibriosis were sampled from traditional brackish water of Wonorejo dan Turunrejo subdistricts (Kendal district) and Margomulyo dan Puncel subdistricts (Pati district) in the north coast of Central Java (Figure 1). The samples were stored in an insulated container and brought to the laboratory for bacterial


Figure 1. Collection sites of the shrimps 
isolation. Shrimp samples were categorized by their length $(16.9-17.2 \mathrm{~cm})$. Then, three individuals of black tiger shrimps ( $P$. monodon) and three individuals of pacific white shrimps (L. vannamei) from each location were sampled randomly. A total of 24 specimens (11 black tiger shrimps and 13 pacific white shrimps) were used as material research.

\section{Bacterial Isolation}

Bacterial isolation was performed by scraping off the telson and inner part of the hepatopancreas with a sterile scalpel. The tissues were serially diluted in $10^{-1}$, $10^{-3}$, and $10^{-5}$ of the resulting paste prepared in sterile water. Then, $50 \mu \mathrm{L}$ aliquots of each dilution were spread on TCBS agar (Oxoid, England) and incubated at room temperature for $48 \mathrm{~h}$ (Brock and Madigan, 1991; Sarjito et al., 2018). Then, colonies with different morphological features were picked up and purified by serially streaking simple colonies on agar plates.

\section{Repetitive-Polymerase Chain Reaction (rep-PCR)}

The bacterial DNA was extracted from a $24 \mathrm{~h}$-broth culture of isolate strains by using the chelex method with slight modification according to the procedure described by de Lamballerie (1992). The rep-PCR method used for typing strains belonging to Vibrio sp. was adopted from previous methods (Brock \& Madigan, 1991; Sarjito et al., 2009; Sarjito et al., 2018). The repPCR oligonucleotide primers evaluated in this study were BOXA1R (5'-CTACGGCAAGGCGACGCTGACG-3'), REP1R-I (5'-IIIICGICGICATCI GGC-3'), and REP2-I (5'IIICGNCGNCATCNGGC-3') (Versalovic, 1994; Sarjito et al., 2012; Prayitno et al., 2015). The PCR product was purified by $\mathrm{GoTaq}^{\circledR}$ Green Master Mix (Promega) following the protocol described by the manufacturer. The reaction mixtures were denaturated at $95^{\circ} \mathrm{C}$ for 5 min, followed by 30 cycles of amplification at $92^{\circ} \mathrm{C}$ for $60 \mathrm{~s}$, annealing at $50^{\circ} \mathrm{C}$ for $90 \mathrm{~s}$, followed by a final extension at $68^{\circ} \mathrm{C}$ for $10 \mathrm{~min}$. The $5 \mu \mathrm{L}$ PCR amplicons were visualized and compared to molecular weight standards (100-basepair ladder) after electrophoresis on $1 \%$ agarose gels staining with ethidium bromide (Prayitno et al., 2015).

\section{Isolate Grouping}

On the basis of electrophoresis results on rep-PCR, the isolates were grouped by analyzing the band position on the gel with the Free Tree program (Hampl et al., 2001; Prayitno et al., 2015). Then, one isolate from each group in the dendrogram tree was chosen randomly for further identification.

\section{Bacterial Identification}

The GM3F and GM4R primers were used to amplify the 16S rRNA gene (Muyzer et al., 1995). Genomic DNA of Vibrio strains was extracted from bacterial cells by using the freeze-thaw method. The 16S rRNA gene amplification, purification, and sequence were carried out as previously described by Radjasa et al. (2007) and Sarjito et al. (2018). PCR products were sequenced and then compared by BLAST homology searching (Altschul et al., 1990; Widowati et al., 2018). The phylogenetic tree was constructed by using the Mega 7 software package (Sibero et al., 2017; Sibero et al., 2018).

\section{Results and Discussion}

\section{Vibriosis Signs and Bacterial Isolation}

Twenty-four shrimps with clinical signs of vibriosis were sampled for Vibrio isolation vibriosis signs were reddish and melanosis in the telson (a), reddish periopods and pleiopods (b), soft body (c), and reddish (Figure 2).

These clinical signs were similar to the results of vibriosis in previous research (Raja et al., 2017; Sarjito et al., 2018). However, the clinical signs previously described by Mastan and Begum (2016), such as loss of appetite, red to brown gills, reduced feeding, empty gut, and general septicemia, were not found in the present research. This result might be due to the different virulence degrees. In addition, the virulence degree of various Vibrio isolates depends on its source and the pond environmental conditions. Even differences occur in the virulence degree of different Vibrio species and isolates. Jayasree et al. (2006) reported that $V$. harveyi isolated from LSS shrimp is the most virulent. Meanwhile, Soto-Rodriguez (2015) showed that $V$. parahaemolyticus is the most virulent. Furthermore, the virulence is generally dependent on the strain, density, infection route, exposure time, species considered, and age and general condition of the shrimp (Alday-Sanz et al., 2002; Saulnier et al., 2000).

Forty-one pure bacterial strains were isolated based on the different morphologies and types of growth on TCBS agar. Table 1 shows that bacterial strains were morphologically characterized by colony form (oval, circular, and irregular) and color (green, black, yellow, and white). Widanarni et al. (2003) reported the bacterial characteristics isolated from tiger shrimp larvae of Labuan, Pangandaran, and Lampung, Indonesia are Gram-negative, short rod-shaped, yellow colonies. Approximately $60 \%$ of bacteria associated with shrimp vibriosis in Sri Lanka belonged to Vibrioceae (Raja et al., 2017). Moreover, the six species of Vibrio were collected from diseased shrimps in the culture ponds of Andhra Pradesh India (Jayasree et al., 2006). Meanwhile, V. parahaemolyticus was isolated from retail shrimp (Letchumanan et al., 2015).

\section{Molecular Identification and Phylogenetic Analysis}

The rep-PCR analysis of 41 bacterial isolates showed that these isolates were classified into five 


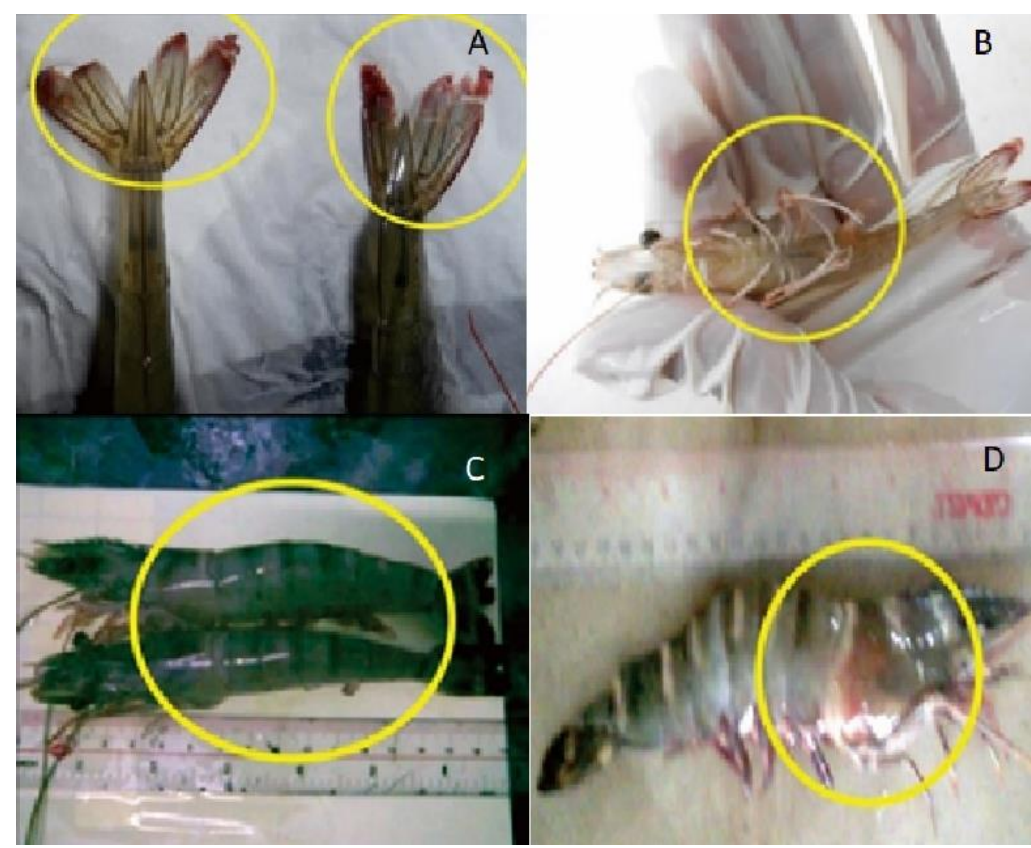

Figure 2. Shrimps with clinical signs of vibriosis (Note: $A=$ reddish and melanosis in a telson, $B=$ reddish in periopods and pleiopods, C=soft body, $D=$ reddish carapace, periopods, pleopods, mouth, and telson carapace, periopods, pleopods, mouth, and telson (d).

Table 1. Bacterial isolates obtained from the telson and inner hepatopancreas of shrimps with vibriosis clinical signs

\begin{tabular}{|c|c|c|c|c|c|c|}
\hline \multirow{2}{*}{ No. } & \multirow{2}{*}{ Isolate code } & \multirow{2}{*}{ Location } & \multirow{2}{*}{ Source of organ } & \multicolumn{3}{|c|}{ Colony } \\
\hline & & & & Color & Form & Characteristic \\
\hline 1 & JKP17 & Pati & Hepatopancreas & Yellow & Oval & Convex \\
\hline 2 & JKM05 & Kendal & Hepatopancreas & Yellow & Rounded & Convex \\
\hline 3 & JKM12 & Kendal & Hepatopancreas & Green & Rounded & Convex \\
\hline 4 & JKP11 & Pati & Hepatopancreas & Yellow & Rounded & Convex \\
\hline 5 & JKM18 & Kendal & Hepatopancreas & Yellow & Rounded & Convex \\
\hline 6 & JKP02 & Pati & Hepatopankreas & Yellow & Rounded & Convex \\
\hline 7 & JKPO3 & Pati & Hepatopancreas & Yellow & Rounded & Flat \\
\hline 8 & JKM11 & Kendal & Hepatopancreas & Black & Rounded & Convex \\
\hline 9 & JKM17 & Kendal & Hepatopancreas & Black & Rounded & Convex \\
\hline 10 & JKP05 & Pati & Hepatopancreas & Yellow & Oval & Convex \\
\hline 11 & JKP12 & Pati & Hepatopancreas & Yellow & Irregular & Flat \\
\hline 12 & JKM07 & Kendal & Hepatopancreas & Yellow & Rounded & Convex \\
\hline 13 & JKM04 & Kendal & Hepatopancreas & Yellow & Rounded & Convex \\
\hline 14 & JKM01 & Kendal & Hepatopancreas & Green & Rounded & Convex \\
\hline 15 & JKP14 & Pati & Hepatopancreas & White & Irregular & Convex \\
\hline 16 & JKP15 & Pati & Hepatopancreas & White & Irregular & Rough \\
\hline 17 & JKM17 & Kendal & Hepatopancreas & Yellow & Rounded & Concave \\
\hline 18 & JKP18 & Pati & Hepatopancreas & Yellow & Rounded & Flat \\
\hline 19 & JKM15 & Kendal & Hepatopancreas & Green & Rounded & Convex \\
\hline 20 & JKM06 & Kendal & Hepatopancreas & Yellow & Rounded & Convex \\
\hline 21 & JKM03 & Kendal & Hepatopancreas & Black & Rounded & Convex \\
\hline 22 & JKM19 & Kendal & Hepatopancreas & Yellow & Rounded & Convex \\
\hline 23 & JKM20 & Kendal & Hepatopankreas & Yellow & Rounded & Convex \\
\hline 24 & JKP10 & Pati & Hepatopancreas & Yellow & Rounded & Convex \\
\hline 25 & JKP19 & Pati & Hepatopancreas & Yellow & Irregular & Rough \\
\hline 26 & JKP16 & Pati & Hepatopancreas & Yellow & Rounded & Rough \\
\hline 27 & JKM14 & Kendal & Hepatopancreas & Black & Rounded & Convex \\
\hline 28 & JKP08 & Pati & Hepatopancreas & Yellow & Rounded & Convex \\
\hline 29 & JKM13 & Kendal & Hepatopancreas & Yellow & Rounded & Convex \\
\hline 30 & JKP06 & Pati & Hepatopancreas & Yellow & Rounded & Convex \\
\hline 31 & JKM08 & Kendal & Hepatopancreas & Yellow & Rounded & Convex \\
\hline 32 & JKM09 & Kendal & Hepatopancreas & Green & Rounded & Convex \\
\hline 33 & JKP07 & Pati & Hepatopancreas & Yellow & Rounded & Convex \\
\hline 34 & JKP01 & Pati & Hepatopancreas & Yellow & Rounded & Convex \\
\hline 35 & JKM11 & Kendal & Hepatopancreas & Yellow & Rounded & Convex \\
\hline 36 & JKP09 & Pati & Hepatopancreas & Green & Rounded & Convex \\
\hline 37 & JKP04 & Pati & Hepatopancreas & Yellow & Oval & Convex \\
\hline 38 & JKM10 & Kendal & Hepatopancreas & Black & Rounded & Convex \\
\hline 39 & JKM02 & Kendal & Hepatopancreas & Yellow & Rounded & Convex \\
\hline 40 & JKM21 & Kendal & Telson & Yellow & Rounded & Convex \\
\hline 41 & JKM22 & Kendal & Telson & Green & Rounded & Convex \\
\hline
\end{tabular}


groups (Figure 3). The five representative isolates, JKP03, JKP05, JKP19, JKM01, and JKM06, of each group were selected randomly for molecular identification (Table 2). Figure 3 and Table 2 demonstrate that $V$. diabolicus (16 isolates) and S. algae (10 isolates) were predominant species in shrimp cultured by traditional shrimp culture technology. $V$. alginolyticus and $V$. rotiferianus were only represented with seven isolates each. The lowest one was $V$. parahaemolyticus (1 strain). These results indicated that the Vibrio species diversity in the north coast of Central Java was higher than the diversity reported in the white pacific shrimp L. vannamaei Kendal (Sarjito et al., 2018) and in P. monodon cultured in Sri Lanka (Heenatigala and Fernando, 2016) and South East Coast of India (Stalin \&
Srinivasan, 2017). The V. rotiferianus, and Shewanella sp. found in the present study were also discovered in Sri Lanka, South East Coast of India, and Sical, Yucatan, Mexico (Heenatigala \& Fernando, 2016; Stalin \& Srinivasan, 2017; Rivera et al., 2019).

Table 2. 16S rDNA-based molecular identification of five Vibrio associated with shrimp vibriosis

The diversity of Vibrio related to vibriosis in shrimps cultured in traditional brackish water ponds in the north coast of Central Java showed that the JKP03, JKP05, JKP19, JKM01, and JKM06 isolates were closely related to $V$. rotiferianus strain HDC47, $V$. parahaemolyticus strain SEM52, V. alginolyticus strain CX-71, and Shewanella algae strain SFH3, respectively (Figure 4). Some previous studies confirmed

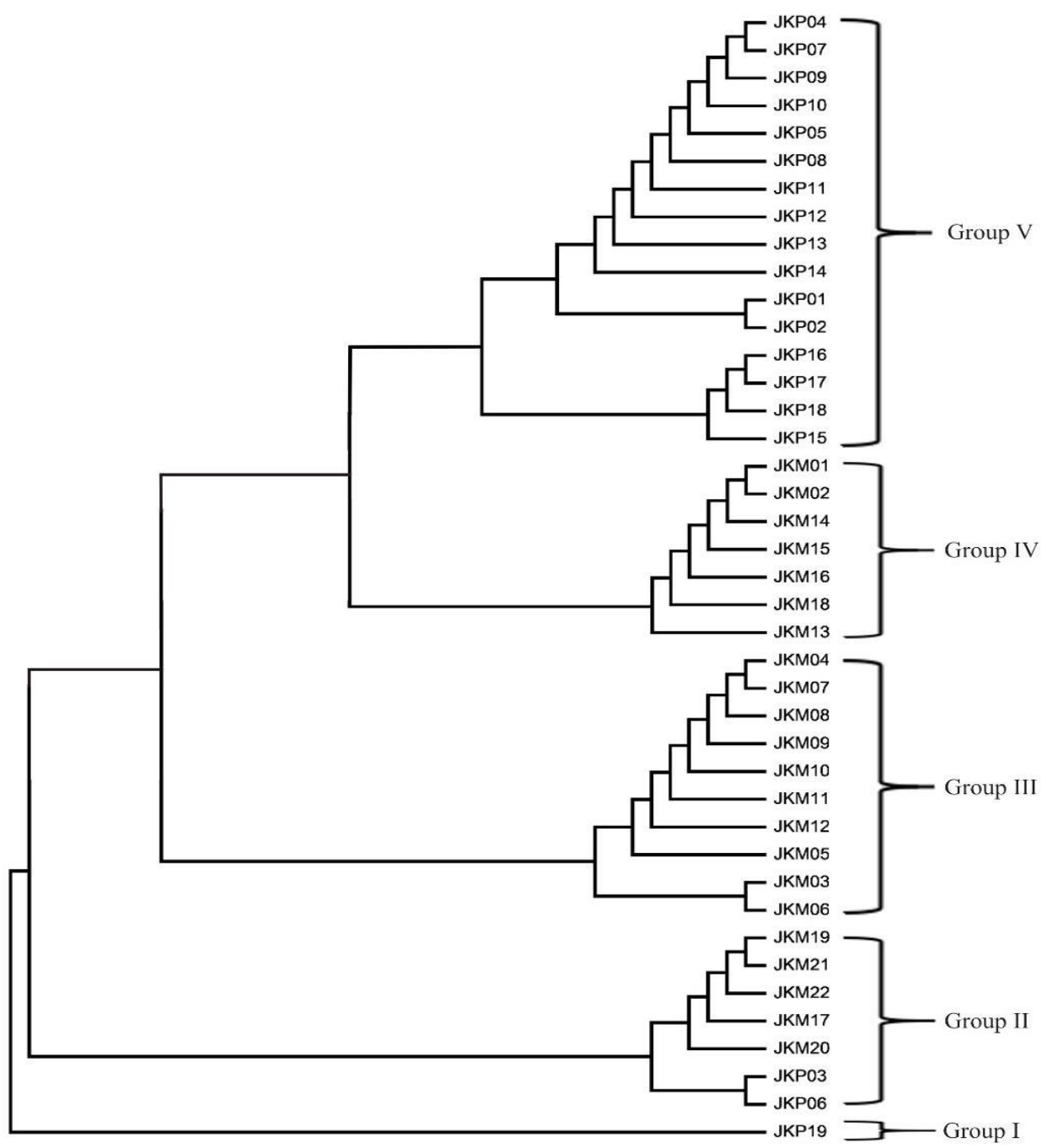

Figure 3. Dendrogram of repetitive PCR of 41 Vibrio isolates in shrimps

Table 2. 16S rDNA-based molecular identification of five Vibrio species associated with shrimp vibriosis

\begin{tabular}{lcccc}
\hline No. & Isolate & Closely Relative & Homology (\%) & Acc. Number \\
\hline 1. & JKP03 & Vibrio rotiferianus & 100 & GQ175915.1 \\
2. & JKP05 & V. diabolicus & 99 & MH044628.1 \\
3. & JKP19 & V. parahaemolyticus & 94 & MG548344.1 \\
4. & JKM01 & V. alginolyticus & 97 & MH368391.1 \\
5. & JKM06 & Shewanella algae & 99 & MG738264.1 \\
\hline
\end{tabular}


that $V$. rotiferianus is a causative agent associated with shrimp Fenneropenaeus chinensis post larvae (Zhang et al., 2014). Meanwhile, V. parahaemolyticus is a pathogenic bacterium in $P$. monodon (Alagappan et al., 2017) and L. vannamei (Kumar et al., 2014; Kongchum et al., 2016; Raja et al., 2017). Further, V. alginolyticus has been found as a pathogenic bacterium in $L$. vannamei in Taiwan (Cheng et al., 2005; Chen et al., 2016; Liu et al., 2004; Wu et al., 2018) and in the grow-out ponds of tiger shrimp ( $P$. monodon) in India and Large Yellow Croaker (Liu et al., 2014; Santhyia et al., 2015; Selvin \& Lipton, 2003; Shanmugasundaram et al., 2015). Recently, $V$. alginolyticus bacterial species have been isolated from corals in India (Deb et al., 2020) and white shrimps in Central Java (Widowati et al., 2018), Bangladesh (Hannan et al., 2019), South India (Biju et al., 2016; Mastan \& Begum 2016), and Malaysia (Muthukrishanana et al., 2019). In addition, they have been related to the stress of white shrimps (Peng et al., 2018).

Surprisingly, $V$. diabolicus was found in the present study. Limited studies reported about $V$. diabolicus associated with vibriosis in brackish water-cultured shrimp. This bacterium is commonly found as a bacterial pathogen in the mussel Bathymodiolus azoricus (Barros et al., 2016), coral Pacillopora verrucosa (Deb et al., 2020), and green mussel (Susilowati et al., 2019). This bacterial species was first found from deep-sea hydrothermal vent polychaete (Deb et al., 2020) and in East Pacific Rise (Turner et al., 2018). Previous studies revealed that $V$. diabolicus might be isolated from polychaete (Raguenes et al., 1997; Rougeaux et al., 1999), horse mackerel, seawater, sediment, dentex, oyster, and artemia collected from China, India, Greece, United States, East Pacific Rise, and Chile (Turner et al., 2018). According to the latest study by Susilowati et al. (2019), V. diabolicus has a known close genetic relationship with $V$. harveyi, $V$. vulnificus, $V$. parahaemolyticus, V. alginolyticus, and V. fischeri. S. algae is normally found in biofloc because it can be used to increase nutritional and disease resistance by application of probiotics (Far et al., 2013; Goudenege et al., 2014; Interaminense et al., 2019). In the present research, S. algae were recovered from shrimp vibriosis. Some previous studies also reported that this bacterium is a bacterial pathogen with massive mortality in Carrasius auratus (Altun et al., 2014), Babylonia spp. (Li et al., 2015), Cynoglossus seilaevis (Han et al., 2017), Haliotis diversicolor, Crassostrea angulate, Meretrix lusoria, Pena viridis, Geloina erosa (Tseng et al., 2018), and freshwater-cultured whiteleg shrimp $P$. vannamei (Cao et al., 2018). Given that vibriosis still exists in farms and continues to grow, control methods such as new vaccines, probiotics, and immunostimulant formulas must be developed for more potent efficacies.

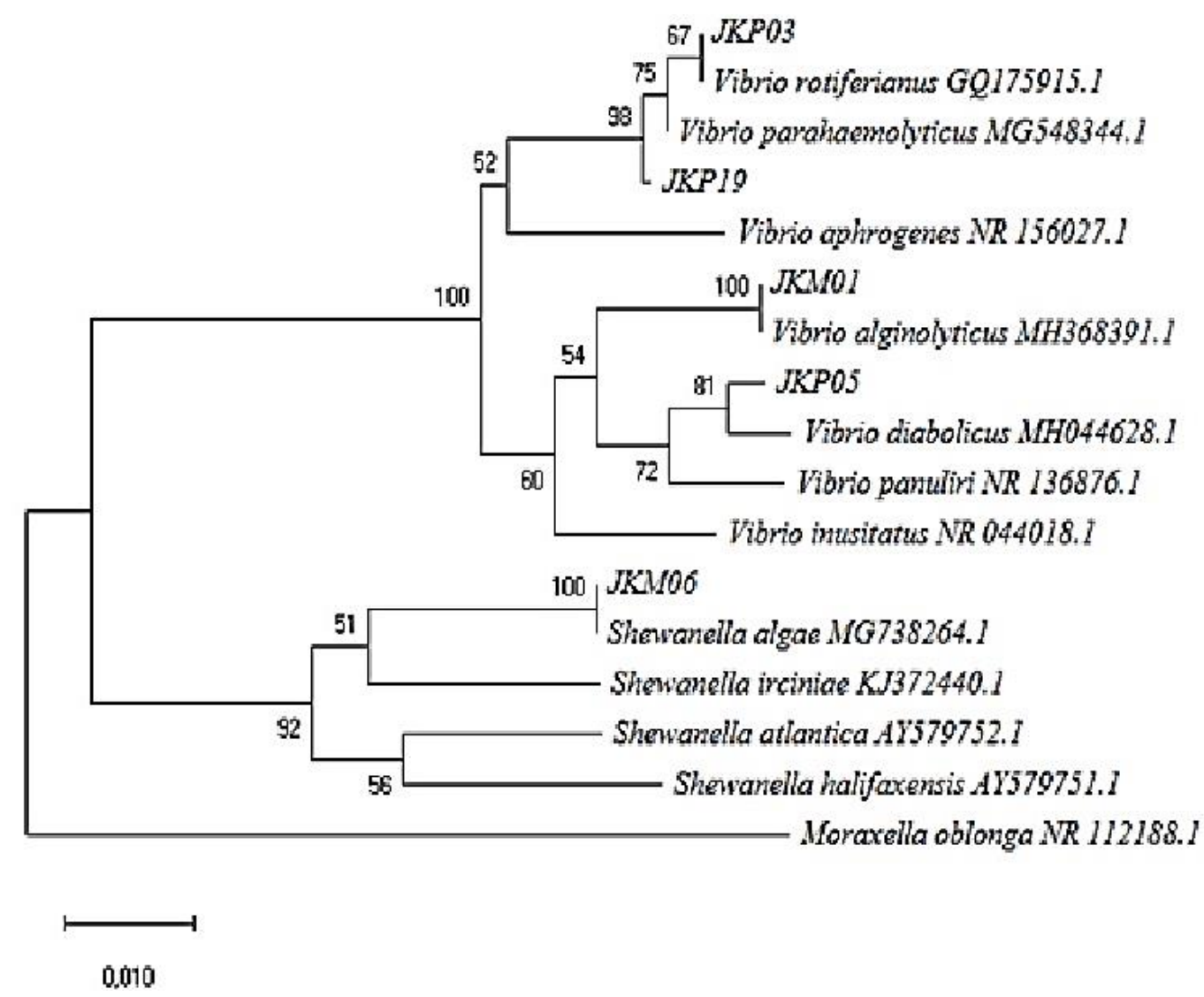

Figure 4. Phylogenetic tree of Vibrio associated with vibriosis in shrimps from traditional brackish water ponds of the northern coast of Central Java. The branching pattern was generated by the neighbor-joining method. Bootstrap values of 700 or more (from 1,000 replicates) are indicated at the nodes. Moraxella oblonga was used as an outgroup. 


\section{Conclusion}

Vibrio associated with vibriosis in shrimps from traditional brackish water ponds of the northern coast of Central Java is present in high diversity. These bacterial associations were identified as $V$. diabolicus, $S$. algae, $V$. alginolyticus, $V$. rotiferianus, and V. parahaemolyticus. Given that vibriosis exists in farms and in high diversity, control methods such as probiotics, new vaccines, and immunostimulant formulas must be developed for further prevention and control of vibriosis in shrimp cultured in traditional brackish water ponds.

\section{Ethical Statement}

The research sample was moribund shrimps or shrimps with clinical symptoms of vibriosis. The shrimp was collected from the traditional brackish water ponds infected by vibriosis. In Indonesia, the ethical clearance commission has not regulated on invertebrates, but only vertebrate, while in the Unites States cephalopods have been added by the committee ethics. In Accordance with the guidelines, EU directive 2010/63/EU for animal experiment and Indonesia regulation, so shrimp sampling, transportation and isolation bacteria from the samples were carried out by observing the principles of animal welfare. All surgical samples were performed under clove oil anesthesia and all efforts were made minimize suffering.

\section{Funding Information}

Our Research Project was partially funded by Advance Research, Fisheries and Marine Science Faculty, Universitas Diponegoro of SUKPA (PNBP) 2018, No: 57502/UN7.5.1/PG/2018 (30,000,000 IDR to SJT), "To investigate the Causative Agent of Diseases in Aquaculture Organism with Molecular Approach". So, the funders had no role in study design, data collection and analysis, decision to publish, or preparation of the manuscript.

\section{Author Contributions}

Conceptualization: SJT, Data Curation: SJT and AS, Formal Analysis: $A S$, Funding Acquisition: $A S$, Investigation: SJT and AS, Methodology: SJT and AS, Project Administration: SJT, Resources: SJT, Software and Supervision: $A S$, visualization and writing original draft: SJT, Writing-review and editing: SJT and AS.

\section{Conflict of Interest}

The authors declare that they have no known competing financial or non-financial, professional, or personal conflicts that could have appeared to influence the work reported in this paper.

The authors have declared no conflict of interest.

\section{Acknowledgments}

The authors would like to thank to our colleagues especially to Professor Slamet Budi Prayitno, Associate Professor Desrina, Associate professor Anindya Wirasatriya and Dr. Mada Triandala Sibero for their suggestion to improve this manuscript. Appreciation goes to the shrimp farmers who have provided the samples. We also thank the Head of Tropical Marine Biotechnology Laboratory and Aquaculture Laboratory of Fisheries and Marine Sciences Faculty, Diponegoro University for providing this research facility.

\section{References}

Abdelaziz, M., Ibrahem, M.D., Ibrahim, M.A., Abu-Elala, N.M., \& Abdel-moneam, D.A. (2017). Monitoring of Different Vibrio Species Affecting Marine Fishes in Lake Qarun and Gulf of Suez: Phenotypic and Molecular Characterization. The Egyptian Journal of Aquatic Research, 43, 141-146. https://doi.org/10.1016/j.ejar.2017.06.002

Akaylı, T., \& Timur, G. (2002). Vibriosis in Gilthead Sea Bream (Sparus aurata L.) in Farms in the Aegean Sea Coast of Turkey. Turkish Journal of Fisheries and Aquatic Sciences, 2, 89-91.

Alagappan, K., Karuppiah, V., \& Deivasigamani, B. (2017). Protective Effect of Phages on Experimental $V$. Parahaemolyticus Infection and Immune Response in Shrimp (Fabricius, 1798). Journal of Aquaculture, 20, 8692. https://doi.org/10.1016/j.aquaculture.2015.11.037

Alday-Sanz, V., Roque, A., \& Turnbull, J.F. (2002). Clearing Mechanisms of Vibrio Vulnificus Biotype I in the Black Tiger Shrimp Penaeus monodon. Diseases of Aquatic Organisms, 48: 91-99

Altschul, S.F., Gish, W., Miller, W., Myers, E.W., \& Lipman, D.J. (1990). Basic Local Alignment Search Tool. Journal of Molecular Biology, 215, 403-410. https://doi.org/10.1016/S0022-2836(05)80360-2

Altun, S., Buyukekiz, A.G., Duman, M., Ozyigit, M.O., Karatas, S., \& Turgay, E. (2014). Isolation of Shewanella putrefaciens from Goldfish (Carassius auratus auratus). Israeli Journal of Aquaculture-Bamidgeh, 956.

Ariyati, R.W., Rejeki, S., Widowati L., Elfitasari, T., \& Bosma, R.H. (2019). Effect of Three Types of Liquid Compost Combined with Avicennia marina Leaves on Growth and Survival of Tiger Prawns (Penaeus monodon). International Aquatic Research, 11, 311-321. https://doi.org/10.1007/s40071-019-00248-w

Austin, B., \& Austin, D.A. (2007). Bacterial Fish Pathogens. Disease in farmed and wild fish. Ellis Horword limited.

Hariati, A.M., Wiadnya, D.G.R., Prajitno, A., Sukkel, M., Boon, J.H., \& Verdegem, M.C.J. (1995). Recent Developments of Shrimp, Penaeus monodon (Fabricius) and Penaeus merguiensis (de Man), Culture in East Java. Aquaculture Research, 26, 819-821. https://doi.org/10.1111/j.13652109.1995.tb00875.x

Barros, I., Mendes, S., Rosa, D., Santos, R.S., \& Bettencourt, R. (2016). Vibrio diabolicus Immunomodulatory Effects on Bathymodiolus azoricus During Long-Term Acclimatization at Atmospheric Pressure. Journal of Aquaculture Research and Development, 7, 1-18. https://doi.org/10.4172/2155-9546.1000464 
Biju, N., Sathiyaraj, G., Raj, M., Shanmugam, V., Baskaran, B., Govindan, U., Kumaresan, G., Kasthuriraju, K.K., \& Chellamma, T.S.R.Y. (2016). High Prevalence of Enterocytozoon hepatopenaei in Shrimps Penaeus monodon and Litopenaeus vannamei Sampled from Slow Growth Ponds in India. Diseases of Aquatic Organisms, 120, 225-230. https://doi.org/10.3354/dao03036

Brock, T.D., \& Madigan, M.T. (1991). Biology of microorganisms. $6^{\text {th }}$ ed. Prentice-Hall.

Cao, H., Chen, S., Lu, L., \& An, J. (2018). Shewanella algae: An Emerging Pathogen of Black Spot Disease in FreshwaterCultured Whiteleg Shrimp (Penaeus vannamei). The Israeli Journal of Aquaculture-Bamidgeh, 70, 1-7.

Chandrakala, N., \& Priya, S. (2017). Vibriosis in Shrimp Aquaculture A Review. International Journal of Scientific Research in Science, Engineering and Technology, 3, 2723.

Chen, Y.Y., Kitikiew, S., Yeh, S.T., \& Chen, J.C. (2016). White Shrimp Litopenaeus vannamei that Have Received Fucoidan Exhibit a Defense Against Vibrio alginolyticus and WSSV Despite Their Recovery of Immune Parameters to Background Levels. Fish and Shellfish Immunology, 59, 414-426. https://doi.org/10.1016/j.fsi.2016.10.050

Cheng, W., Wang, L.U., \& Chen, J.C. (2005). Effect of Water Temperature on the Immune Response of White Shrimp Litopenaeus vannamei to Vibrio alginolyticus. Aquaculture, 250, 592-601. https://doi.org/10.1016/j.aquaculture.2005.04.060

Chythanya, R., Karunasagar, I., \& Karunasagar, I. (2002). Inhibition of Shrimp Pathogenic Vibrios by a Marine Pseudomonas I-2 Strain. Aquaculture, 208, 1-10. https://doi.org/10.1016/S0044-8486(01)00714-1

de Lamballerie, X., Zandotti, C., Vignoli, C., Bollet, C., \& de Micco, P. (1992). A One-Step Microbial DNA Extraction Method Using 'Chelex 100' Suitable for Gene Amplification. Journal Research in Microbiology, 143, 785-790. https://doi.org/10.1016/0923-2508(92)90107-Y

Deb, S., Badhai, J., \& Das, S.K. (2020). Draft Genome Sequences of Vibrio alginolyticus Strain S6-61 and Vibrio diabolicus Strain S7-71, Isolated from Corals in the Andaman Sea. Microbiology Resource Announcements, 9, e01465-19. https://doi.org/10.1128/MRA.01465-19

Far, H.Z., Saad, C.R.B., Daud, H.M., Kamarudin, M.S., \& Fard, E.R. (2013). Isolation and Identification of Bacteria Micro Flora of White Shrimp, Litopenaeus vannamei, with Antagonistic Properties Against Vibrio Species. Asian Journal of Animal and Veterinary Sciences, 8, 293-300. https://doi.org/10.3923/ajava.2013.293.300

Gopal, S., Otta, S.K., Kumar, S., Karunasagar, I., Nishibuchi, M., \& Karunasagar, I. (2005). The Occurrence of Vibrio Species in Tropical Shrimp Culture Environments; Implications for Food Safety. International Journal of Food Microbiology, 102, 151-159. https://doi.org/10.1016/j.ijfoodmicro.2004.12.011

Goudenege, D., Boursicot, V., Versigny, T., Bonnetot, S., Ratiskol, J., Sinquin, C., Lapointe, G., Roux, F.L., \& Ladrat, C.D. (2014). Genome Sequence of Vibrio diabolicus and Identification of the Exopolysaccharide HE800 Biosynthesis Locus. Applied Genetics and Molecular Biotechnology, 98, 10165-10176. http://dx.doi.org/10.1007/s00253-014-6202-9

Hampl, V., Pavlícek, A., \& Flegr, J. (2001). Construction and Bootstrap Analysis of DNA Fingerprinting-Based
Phylogenetic Trees with a Freeware Program FreeTree: Application to Trichomonad Parasites. International Journal of Systematic and Evolutionary Microbiology, 51, 731-735.

Han, Z., Sun, J., Lv, A., Sung, Y., Shi, H., Hu, X., \& Xing, K. (2017). Isolation, Identification and Characterization of Shewanella algae from Reared Tongue Sole, Cynoglossus semilaevis Günther. Aquaculture, 468, 356-362. https://doi.org/10.1016/j.aquaculture.2016.10.038

Hannan, M.A., Rahman, M.M., Mondal, M.N., Deb, S.C., Chowdhury, G., \& Islam, M.T. (2019). Molecular Identification of Vibrio alginolyticus Causing Vibriosis in Shrimp and Its Herbal Remedy. Polish Journal of Microbiology, 68, 429-438.

https://doi.org/10.33073/pjm-2019-042

Heenatigala, P.P.M., \& Fernando, M.U.L. (2016). Occurrence of Bacteria Species Responsible for Vibriosis in Shrimp Pond Culture Systems in Sri Lanka and Assessment of the Suitable Control Measures. Sri Lanka. Journal of Aquatic Sciences, 21, 1-17.

https://doi.org/10.4038/sljas.v21i1.7481

Interaminense, J.A., Vogeley, J.L., Gouveia, C.K., Portela, R.S., Oliveira, J.P., Silva, S.M.B.C., Coimbra, M.R.M., Peixoto, S.M., Soares, R.B., Buarque, D.S., \& Bezerra, R.S. (2019). Effects of Dietary Bacillus subtilis and Shewanella algae in Expression Profile of Immune-Related Genes from Hemolymph of Litopenaeus vannamei Challenged with Vibrio parahaemlyticus. Fish and Shellfish Immunology, 86, 253-259. https://doi.org/10.1016/j.fsi.2018.11.051

Isnansetyo, A., Istiqomah, I., Muhtad, Sinansari, S., Hernawan, R.K., Triyanto, \& Widada, J. (2009). A Potential Bacterial Biocontrol Agent, Strain S2V2 Against Pathogenic Marine Vibrio in Aquaculture. World Journal of Microbiology and Biotechnology, 25, 1103-1113. https://doi.org/10.1007/s11274-009-9992-7

Istiqomah, I., \& Isnansetyo, A (2020). Review: Vibriosis Management in Indonesian Marine Fish Farming. E3S Web of Conferences, 147, 01001. https://doi.org/10.1051/e3sconf/202014701001

Jayasree, L., Janakiram, P., \& Madhavi, R. (2006). Characterization of Vibrio spp. Associated with Diseased Shrimp from Culture Ponds of Andhra Pradesh (India). Journal of the World Aquaculture Society, 37, 523-532. https://doi.org/10.1111/j.1749-7345.2006.00066.x

Kongchum, P., Chimtong, S., Chareansak, N., \& Subprasert, P. (2016). Effect of Green Tean Extract on Vibrio parahaemolyticusInhibition in Pacific White Shrimp (Litopenaeus vannamei) Postlarvae. Agriculture and Agricultural Science Procedia, 11, 117-124. https://doi.org/10.1016/j.aaspro.2016.12.020

Kumar, B.K., Deekshit, V.K., Raj, R.M., Rai, P., Shivanagowda, B.M., \& Karunasagar, I. (2014). The Diversity of Vibrio parahaemolyticus Associated with Disease Outbreak Among Cultured Litopenaeus vannamei (Pacific White Shrimp) in India. Aquaculture, 433, 247-251. https://doi.org/10.1016/j.aquaculture.2014.06.016

Letchumanan, V., Yin, W.F., \& Chan, K.G., (2015). Prevalence and Antimicrobial Susceptibility of Vibrio parahaemolyticus Isolated from Retail Shrimps in Malaysia. Frontiers in Microbiololgy, 15, 1-11. https://doi.org/10.3389/fmicb.2015.00033.

Li, S., Zhang, J., Qiu, D., Yang, S., \& Huang, Z. (2015). Biological Characteristics and Pathogenicities of Shewanella algae and Shewanella abalone from Babylonia. Agricultural Science and Technology, 16, 9, 1845-1859. 
Lightner, D.V.A. (1996). Hand book of Shrimp Pathology and Diagnostic Procedures for Diseases of Culture Penaeid Shrimp in Asia. World Aquaculture Society.

Liu, L., Ge, M., Zheng, X., Tao, Z., Zhou, S., \& Wang, G. (2016). Investigation of Vibrio alginolyticus, $V$. harveyi, and $V$. parahaemolyticusin Large Yellow Croaker, Pseudosciaena crocea (Richardson) Reared in Xiangshan Bay, China. Aquaculture Reports, 3, 220-224. https://doi.org/10.1016/j.aqrep.2016.04.004

Liu, C.H., Cheng, W., Hsu, J.P., \& Chen, J.C. (2004). Vibrio alginolyticus Infection in the White Shrimp Litopenaeus vannamei Confirmed by Polymerase Chain Reaction and 165 rDNA Sequencing. Diseases of Aquatic Organisms, 61, 169-174. https://doi.org/10.3354/dao061169

Liu, Y., Hou, F., He, S., Qian, Z., Wang, X., Mao, A., Sun, C., \& Liu, X. (2014). Identification, Characterization and Functional Analysis of a Serine Protease Inhibitor (Lvserpin) from the Pacific White Shrimp, Litopenaeus vannamei. Developmental and Comparative Immunology, 43, 35-46.

https://doi.org/10.1016/j.dci.2013.10.012

MacDonell, M. T., \& Cowell, R.R. (1985). Phylogeny of Vibrionaceae, and Recommendation for Two New Genera, Listonella and Shewanella. Systematics and Applied Microbiology, 6, 171-182. https://doi.org/10.1016/S0723-2020(85)80051-5

Mastan, S.A., \& Begum, S.K.A. (2016). Vibriosis in Farm Reared White Shrimp, Litopenaeus vannamei in Andhra Pradesh-Natural Occurrence and Artificial Challenge. International Journal of Applied Sciences and Biotechnology, 4(2), 217-222.

https://doi.org/10.3126/ijasbt.v4i2.15126

Muthukrishanana, S., Defoirdt, T., Salwany, M.Y.I, Yusoff, F.M., Shariff, M., Ismail, S.I., \& Natrah, I. (2019). Vibrio parahaemolyticus and Vibrio harveyi Acute Hepatopancreatic Necrosis Disease (AHPND) in Penaeus vannamei (Boone, 1931) Isolated from Malaysian Shrimp Ponds. Aquaculture, 511.

https://doi.org/10.1016/j.aquaculture.2019.734227

Muyzer, G., Teske, A., Wirsen, C.O., \& Jannasch, H.W. (1995). Phylogenetic Relationships of Thiomicrospira Species and Their Identification in Deep-Sea Hydrothermal Vent Samples by Denaturing Gradient Gel Electrophoresis of $16 \mathrm{~S}$ rDNA Fragments. Archives of Microbiology, 164, 165-172.

Peng, T., Kan, J., Lun, J., \& Hu, Z. (2019). Identification of Novel sRNAs Involved in Oxidative Stress Response in the Fish Pathogen Vibrio alginolyticus by Transcriptome Analysis. Journal of Fish Diseases, 42, 277-291. https://doi.org/10.1111/jfd.12926

Prayitno, S.B., Sarwan, \& Sarjito. (2015). The Diversity of Gut Bacteria Associated with Milkfish (Chanos chanos Forskal) Northern Coast of Central Java, Indonesia. Procedia Environmental Sciences, 23, 375-384. https://doi.org/10.1016/j.proenv.2015.01.054

Radjasa, O.K., Salasia, S.I.O., Sabdono, S., Weise, J., Imhoff, J.F, Lammler, C., \& Risk, M.J. (2007). Antibacterial Activity of Marine Bacterium Pseudomonas Sp. Associated with Soft Coral Sinularia polydactyla Against Streptococcus Equisubsp. Zooepidemicus. International Journal of Pharmacology, 2, 170-174.

https://doi.org/10.3923/ijp.2007.170.174

Raguénès, G., Christen, R., Guezennec, J., Pignet, P., \& Barbier, G. (1997). Vibrio diabolicus sp. Nov., A New Polysaccharide-Secreting Organism Isolated from a
Deep-Sea Hydrothermal Vent Polychaete Annelid, Alvinella pompejana. International Journal of Systematic Bacteriology, 47, 989-995.

https://doi.org/10.1099/00207713-47-4-989

Raja, A.R., Sridhar, R., Balachandran, C., Palanisammi, A., Ramesh, S., \& Nagarajan, K. (2017). Pathogenicity Profile of Vibrio parahaemolyticus in Farmed Pacific White Shrimp, Penaeus vannamei. Fish and Shellfish Immunology, 67, 268-381.

https://doi.org/10.1016/j.fsi.2017.06.020

Rivera, D.A., Fuentes, G.R., Herrera, K.S.E., Castaro, E.G., Davo, A.P., \& Gaxiola, G. (2019). Differential Expression of Immune-Related Genes in Pacific White Shrimp, Litopenaeus vannamei, Previously Reared in Biofloc and Challenged with Vibrio harveyi. Aquaculture Research, 50(8), 2039-2048. https://doi.org/10.1111/are.14063

Rougeaux, H., Kervarec, N., Pichon, R., \& Guezennec, J. (1999). Structure of the Exopolysaccharide of Vibrio diabolicus Isolated from a Deep-Sea Hydrothermal Vent. Carbohydrate Research, 322, 40-45. https://doi.org/10.1016/s0008-6215(99)00214-1

Santhyia, A.V., Mulloorpeedikayil, R.G., Kollanoor, R.J., \& Jeyaseelan, P.M.J. (2015). Molecular Variations in Vibrio alginolyticus and $V$. harveyi in Shrimp-Farming System upon Stress. Brazilian Journal of Microbiology, 46, 10011008.

https://doi.org/10.1590/S1517-838246420140410

Sarjito, Radjasa, O.K., Sabdono, A., Prayitno, S.B., \& Hutabarat, S. (2009). Phylogenetic Diversity of the Causative Agents of Vibriosis Associated with Groupers Fish from Karimunjawa Islands, Indonesia. Current Research in Bacteriology, 2, 14-21.

https://doi.org/10.3923/crb.2009.14.21

Sarjito, Ningrum, N.W.E., Radjasa, O.K., \& Prayitno, S.B. (2012). Application of Repetitive Sequence-Based PCR on the Richness of Vibrio on the Tiger Shrimp (Penaeus monodon Fab.). Journal of Coastal Development, 15, 303-309.

Haditomo, A.H.C., Djunaedi, A., \& Prayitno, S.B. (2018). The Diversity of Vibrios Associated with Vibriosis in Pacific White Shrimp (Litopenaeus vannamei) from Extensive Shrimp Pond in Kendal District, Indonesia. IOP Conference Series: Earth and Environmental Science, 116. https://doi.org/10.1088/1755-1315/116/1/012011

Saulnier, D., Haffner, P., Goarant, C., Levy, P., \& Ansquer, D. (2000). Experimental Infection Models for Shrimps vibriosis Studies: A Review. Aquaculture, 191, 133-144. vibriosis studies: a review. https://doi.org/10.1016/S0044-8486(00)00423-3

Selvin, J., \& Lipton, A.P. (2003). Vibrio alginolyticus Associated with White Spot Disease of Penaeus monodon. Diseases of Aquatic Organisms, 57, 147-150. https://doi.org/10.3354/dao057147

Setiawan, W.A., Widyastuti, U., \& Yuhana, M. (2015). Detection of Luminous Vibrio Harveyiln Penaeid ShrimpThrough Nested PCR Using Haemolysin Gene Primer. HAYATI Journal of Biosciences, 22, 60-66. https://doi.org/10.4308/hjb.22.2.60

Shanmugasundaram, S., Mayavu, P., Manikandarajan, T., Suriya, M., Annadurai, E., \& Anbarasu, R. (2015). Isolation and Identification of Vibrio sp. In the Hepatopancreas of Cultured White Pacific Shrimp (Litopenaeus vannamei). International Letters of Natural Sciences, 46, 52-59.

https://doi.org/10.18052/www.scipress.com/ILNS.46.52 
Sibero, M.T., Sabdaningsih, A., Cristianawati, O., Nuryadi, H., Radjasa, O.K., Sabdono, A., \& Trento, A. (2017). Isolation, Identification, and Screening of Antibacterial Activity from Marine Sponge-Associated Fungi Against Multidrug-Resistant (MDR) Escherichia coli. IOP Conference Series: Earth and Environmental Science, 55, 012028.

https://doi.org/doi:10.1088/1755-1315/55/1/012028

Sibero, M.T., Radjasa, O.K., Sabdono, A., Trianto, A., Triningsih, D.W., \& Hutagaol, I.D. (2018). Antibacterial Activity of Indonesian Sponge-Associated Fungi Against Clinical Pathogenic Multidrug-Resistant Bacteria. Journal of Applied Pharmaceutical Science, 8, 88-94. https://doi.org/10.7324/JAPS.2018.8214

Soto-Rodriguez, S.A. Gomez Gil, B., Lozano-Olvera, R., Betancourt-Lozano, M. \& Morales-Covarrubias, M.S. (2015). Field and Experimental Evidence of Vibrio parahaemolyticus as the Causative Agent of Acute Hepatopancreatic Necrosis Disease of Cultured Shrimp (Litopenaeus vannamei) in Northwestern Mexico. Applied and Environmental Microbiology, 81, 16891699. doi: 10.1128/AEM.03610-14

Stalin, N., \& Srinivasan, P. (2017). Efficacy of Potential Phage Cocktails Against Vibrio harveyi and Closely Related Vibrio Species Isolated from Shrimp Aquaculture Environment in the South East Coast of India. Veterinary Microbiology, 207, 83-96. https://doi.org/10.1016/j.vetmic.2017.06.006

Susilowati, A., Hikmawati, F., \& Setyaningsih, R. (2019). Colony Morphology and Molecular Identification of Vibrio spp. On Green Mussels (Perna viridis) in Yogyakarta, Indonesia Tourism Beach Areas. Biodiversitas Journal of Biological Diversity, 20(10), 2891-2899. https://doi.org/10.13057/biodiv/d201015

Tseng, S.Y., Liu, P.Y., Lee, Y.H., Wu, Z.Y., Huang, C.C., Cheng, C.C., \& Tung, K.C. (2018). The Patogenicity of Shewanella algae and Ability to Tolerate a Wide Range of Temperatures and Salinities. Canadian Journal of Infectious Diseases and Medical Microbiology, 1-9. https://doi.org/10.1155/2018/6976897

Turner, J.W., Tallman, J.J., Macias, A., Pinnell, L.J., Elledge, N.C.,
Azadani, D.N., Nilsson, W.B., Paranjpye, R.N., Armbrust, E.V., \& Strom, M.S. (2018). Comparative Genomic Analysis of Vibrio diabolicus and Six Taxonomic Synonyms: A First Look at the Distribution and Diversity of the Expanded Species. Frontiers in Microbiology, 9(1893), 1-14.

https://doi.org/10.3389/fmicb.2018.01893

Uddin, S.A., Kader, M.A., Sikder, M., \& Hakim, M.A. (2013). Study of Probiotics on the Seed Production of Black Tiger Shrimp Penaeus monodon. Croatian Journal of Fisheries, 71, 124-130. https://hrcak.srce.hr/108851

Versalovic, J., Schneider, C., de Bruin, F.T., \& Lupski, J.R. (1994). Genomic Finger Printing of Bacteria Using Repetitive Sequence-Based Polymerase Chain Reaction. Method in Moleculer and Cellular Biology, 5, 25-40.

Widanarni, Suwanto, A., Sukenda \& Lay, B.W. (2003). Potency of Vibrio Isolates for Biocontrol of Vibriosis in Tiger Shrimp (Penaeus Monodon) Larvae. The Southeast Asian Journal of Tropical Biology, 20, 11-23. http://dx.doi.org/10.11598/Btb.2003.0.20.180

Widowati, I., Zainuri, M., Kusumaningrum, H.P., Maesaroh, Y., Hardivillier, Y., Leignel, V., Bourgougnon, N., \& Mouget J.L. (2018). Identification of Agents Causing Vibriosis in Litopenaeus vannamei Shrimps Culture in Kendal, Central Java, Indonesia and Application of Microalgae Dunaliella salina and Tetraselmis chui as Bio-Control Agents Against Vibriosis. Aquaculture, Aquarium, Conservation \& Legislation-International Journal of the Bioflux Society, 11(1), 101-107.

Wu, C.C., Lin, C.L., Huang, C.Y., Hsieh, S., Liu, C.H., \& Hsieh, S.L. (2019). Alpha-Phellandrene Enhances the Immune Response and Resistance against Vibrio alginolyticus in White Shrimp (Litopenaeus vannamei). Fish and Shellfish Immunology, 84, 1108-1114. https://doi.org/10.1016/j.fsi.2018.11.013

Zhang, X.J., Yan, B.L., Bai, X.S., Bi, K.R., Gao, H., \& Qin, G.M. (2014). Isolation and Characterization of Vibrio parahaemolyticus and Vibrio rotiferianus Associated with Mass Mortality of Chinese Shrimp (Fenneropenaeus chinensis). Journal of Shellfish Research, 33, 61-68. https://doi.org/10.2983/035.033.0108 